\title{
A strain of Meyerozyma guilliermondii isolated from sugarcane juice is able to grow and ferment pentoses in synthetic and bagasse hydrolysate media
}

\author{
Cristina Martini $^{1,2}$ - Sâmia Maria Tauk-Tornisielo ${ }^{2}$ - Carolina Brito Codato ${ }^{1}$. \\ Reinaldo Gaspar Bastos ${ }^{1} \cdot$ Sandra Regina Ceccato-Antonini ${ }^{1}$
}

Received: 5 April 2015/Accepted: 20 February 2016/Published online: 2 April 2016

(C) Springer Science+Business Media Dordrecht 2016

\begin{abstract}
The search for new microbial strains that are able to withstand inhibitors released from hemicellulosic hydrolysis and are also still able to convert sugars in ethanol/xylitol is highly desirable. A yeast strain isolated from sugarcane juice and identified as Meyerozyma guilliermondii was evaluated for the ability to grow and ferment pentoses in synthetic media and in sugarcane bagasse hydrolysate. The yeast grew in xylose, arabinose and glucose at the same rate at an initial medium $\mathrm{pH}$ of 5.5. At $\mathrm{pH}$ 4.5 , the yeast grew more slowly in arabinose. There was no sugar exhaustion within $60 \mathrm{~h}$. At higher xylose concentrations with a higher initial cell concentration, sugar was exhausted within $96 \mathrm{~h}$ at $\mathrm{pH} 4.5$. An increase of $350 \%$ in biomass was obtained in detoxified hydrolysates, whereas supplementation with $3 \mathrm{~g} / \mathrm{L}$ yeast extract increased biomass production by approximately $40 \%$. Ethanol and xylitol were produced more significantly in supplemented hydrolysates regardless of detoxification. Xylose consumption was enhanced in supplemented hydrolysates and arabinose was consumed only when xylose and glucose were no longer available. Supplementation had a greater impact on ethanol yield and productivity than detoxification; however, the product yields obtained in the present study are still much lower when compared to other yeast species in bagasse hydrolysate. By the other hand, the
\end{abstract}

Sandra Regina Ceccato-Antonini

antonini@cca.ufscar.br

1 Department of Tecnologia Agroindustrial e Socio-Economia Rural, Universidade Federal de São Carlos - Centro de Ciencias Agrarias, Via Anhanguera, km 174, Araras, SP 13600-970, Brazil

2 Centro de Estudos Ambientais, Universidade Estadual Paulista Julio de Mesquita Filho, Avenida 24-A, 1515, Rio Claro, SP 13506-900, Brazil fermentation of both xylose and arabinose and capability of withstanding inhibitors are important characteristics of the strain assayed.

Keywords Xylose fermentation - Bagasse hydrolysate . Biomass $\cdot$ Ethanol $\cdot$ Xylitol

\section{Introduction}

The abundance of plant biomass on earth has led to potential prospects for utilizing this raw material as a substrate for second-generation bioethanol (Laluce et al. 2012). This source is not readily available for the microbial transformation of sugars to ethanol because cellulose and hemicellulose in the biomass are associated in a very complex structure in the cell wall (Souza et al. 2012).

The conversion of lignocelluloses into ethanol comprises three main steps: pre-treatment, hydrolysis and fermentation. Physical and chemical methods are employed both in the first and the second steps and, depending on the process utilized, inhibitor substances are released in the hydrolysate, causing decreased product yields and limited microbial growth in the fermentation step (Laluce et al. 2012).

The yeast Saccharomyces cerevisiae is the preferred microorganism for ethanol fermentation due to its ability to grow in simple sugars such as disaccharides. However, it cannot ferment pentoses (Kumar et al. 2009). Natural strains of xylose-fermenting yeasts as Pichia stipitis, Candida shehatae, Pachysolen tannophilus and Kluyveromyces marxianus have been the most exhaustively investigated organisms and are the most efficient xylose fermenters (Olsson and Hahn-Hagerdal 1996; Laluce et al. 2012). More recently, yeast species such as Scheffersomyces shehatae (Antunes et al. 2013) and Spathaspora arborariae (Cadete 
et al. 2009), isolated from Brazilian biodiversity, appear to be prospective ethanol-producing microorganisms from pentoses. However, high yields of ethanol from pentose sugars are still a challenge in addition to the fact that yeasts also must tolerate the inhibitors released during the process of substrate hydrolysis (Chandel et al. 2011). In this context, the search for native yeasts that ferment hemicellulosic sugars and are able to withstand fermentation inhibitors is desirable.

Cadete et al. (2012) demonstrated the promise of using new D-xylose-fermenting yeast strains from the Brazilian Amazonian Forest for ethanol or xylitol production from sugarcane bagasse hemicellulosic hydrolysates. Among the new species assayed, Spathaspora passalidarum demonstrated the highest ethanol yields $(0.31-0.37 \mathrm{~g} / \mathrm{g})$ and productivities $(0.62-0.75 \mathrm{~g} / \mathrm{L} \mathrm{h})$. Rao et al. (2008) isolated yeast strains producing ethanol from xylose from a variety of rotten fruits and tree barks. Members of the genera Pichia, Candida, Kluyveromyces, Issatchenkia, Zygossacharomyces, among others, were able to assimilate xylose and produce $0.12-0.38 \mathrm{~g}$ of ethanol per $\mathrm{g}$ of xylose.

Meyerozyma (Pichia) guilliermondii is a yeast widely distributed in the environment and has been isolated from tree and insect exudates (Araujo et al. 1995; Sibirny 1996), soil, plants (Capriotti and Ranieri 1964), atmosphere, sea water, processed foods (Diriye et al. 1993), rotting wood (Cadete et al. 2012), and spoiled orange juice (Guo et al. 2012). Strains of $M$. guilliermondii have been shown to possess antifungal activities (Lima et al. 2012; Coda et al. 2013) and phosphate-solubilizing activity (Nakayan et al. 2013) and are reported to be good ethanol producers from xylose (Sreenath and Jeffries 2000; Rao et al. 2004; Matos et al. 2014).

In this context and considering that the efficient utilization of pentoses is crucial, this work aimed to evaluate the ability of a strain of Meyerozyma guilliermondii that was isolated from sugarcane juice to grow and ferment pentoses both in synthetic and bagasse hydrolysate media. The fermentation of both xylose and arabinose and the capability to withstand inhibitors are important characteristics of this strain. The effects of the detoxification and supplementation of the sugarcane bagasse hydrolysate on the alcohol and xylitol production of the yeast strain were also verified. This evaluation is a priority within the scope of integral use of hemicellulose-based substrates.

\section{Materials and methods}

\section{Yeast isolation and identification}

A strain of $M$. guilliermondii (CCT7783, strain deposited at Centro de Culturas Tropical-Fundação André Tosello, Campinas, São Paulo, Brasil) was isolated from sugarcane juice and initially screened for pentose fermentation by gas production in a Durham tube with medium containing xylose and arabinose as the sole carbon source. The strain was identified by the amplification of D1/D2 domains of the large subunit of the rRNA gene. The procedures of isolation, preliminary fermentation and identification are described by Martini (2014). The culture was maintained on YPD ( $1 \%$ yeast extract, $2 \%$ glucose, $2 \%$ peptone, $2 \%$ agar; for broth, agar was not included) slants at $4{ }^{\circ} \mathrm{C}$ with regular transfers to new medium.

\section{Growth assays on different carbon sources and initial $\mathrm{pH}$ values in synthetic medium}

The inoculum was prepared by inoculating two loops of cells in $10 \mathrm{~mL}$ of YPD broth and incubating overnight at $30{ }^{\circ} \mathrm{C}$ under agitation at $160 \mathrm{rpm}$. Then, the biomass obtained was washed with saline solution $(\mathrm{NaCl} 0.85 \%)$, centrifuged and diluted until an optical density of 0.5 at $600 \mathrm{~nm}$ (approximately $0.2-0.3 \mathrm{~g} / \mathrm{L}$ biomass dry weight) was reached as an initial value. The growth medium consisted of $6.7 \mathrm{~g} / \mathrm{L}$ Yeast Nitrogen Base with aminoacids and ammonium sulphate $\left(\right.$ Difco $^{\circledR}$ ) as well as glucose or arabinose or xylose at $20 \mathrm{~g} / \mathrm{L}$ as a final concentration in $250-\mathrm{mL}$ Erlenmeyer flasks with a 50-mL final volume and $10 \%$ inoculum $(\mathrm{v} / \mathrm{v})$. The initial $\mathrm{pH}$ of the growth media was adjusted to 4.5 or 5.5 with $1 \mathrm{~mol} / \mathrm{L} \mathrm{HCl}$. The flasks were incubated at $30{ }^{\circ} \mathrm{C}$ in a shaker at $150 \mathrm{rpm}$ for $72 \mathrm{~h}$. Samples were removed every $12 \mathrm{~h}$ for analysis.

\section{Fermentation assays at different $\mathrm{pH}$ values in synthetic medium with xylose as the sole carbon source}

The inoculum was prepared by inoculating two loops of cells in $10 \mathrm{~mL}$ of YPD broth and incubating overnight at $30{ }^{\circ} \mathrm{C}$ under agitation at $160 \mathrm{rpm}$. Then, the biomass obtained was washed with vsaline solution $(\mathrm{NaCl} 0.85 \%)$, centrifuged and added to new YPD broth for a new round of growth. The procedures were repeated until a concentration of an optical density of 2.0 at $600 \mathrm{~nm}$ (approximately $1.0-1.5 \mathrm{~g} / \mathrm{L}$ biomass dry weight) was achieved. The fermentation medium consisted of $5 \mathrm{~g} / \mathrm{L}$ potassium dihydrogen phosphate, $1 \mathrm{~g} / \mathrm{L}$ potassium chloride, $1.5 \mathrm{~g} / \mathrm{L}$ ammonium chloride, $1 \mathrm{~g} / \mathrm{L}$ magnesium sulphate heptahydrate, $6 \mathrm{~g} / \mathrm{L}$ yeast extract and xylose as the sole carbon source at a concentration of $40 \mathrm{~g} / \mathrm{L}$ in $500-\mathrm{mL}$ Erlenmeyer flasks with a $200-\mathrm{mL}$ final volume and $10 \%$ inoculum (v/ $\mathrm{v})$. The initial $\mathrm{pH}$ of the fermentation media was adjusted to 4.5 or 5.5 with $1 \mathrm{~mol} / \mathrm{L} \mathrm{HCl}$. The flasks were incubated at $30{ }^{\circ} \mathrm{C}$ in a shaker at $150 \mathrm{rpm}$ for $120 \mathrm{~h}$. Samples were removed every $24 \mathrm{~h}$ for analysis. 


\section{Fermentation assays in sugarcane bagasse hydrolysate}

\section{Experimental design}

Fermentation assays were performed with sugarcane bagasse hydrolysate, either detoxified or without detoxification and supplemented with or without yeast extract, in a factorial design of $2^{2}$ with two replications.

\section{Hydrolysate preparation}

Sugarcane bagasse was supplied by a local ethanol-producing unit (Usina Santa Lúcia, Araras, SP, Brazil). Hemicellulosic hydrolysate was prepared according to Carneiro (2011) with modifications. Sugarcane bagasse was initially milled and separated in sieves to obtain an average particle diameter of $0.59-0.84 \mathrm{~mm}$. The bagasse particles were washed with distilled water and allowed to dry at $40{ }^{\circ} \mathrm{C}$ for $24 \mathrm{~h}$. An amount of $50 \mathrm{~g}$ of dried bagasse was transferred to glass containers with sulphuric acid at a proportion of $100 \mathrm{mg}$ of sulphuric acid/g dried bagasse in a ratio of 1:10 solid/liquid. The hydrolysis reaction was performed at $120{ }^{\circ} \mathrm{C}$ and $1 \mathrm{~atm}$ of pressure gauge for $50 \mathrm{~min}$ in an autoclave. Then, the hydrolysate was separated from the bagasse by vacuum-filtration and pressing, and the reducing sugars were determined in the hydrolysate. The hydrolysate had a $\mathrm{pH} 1.7$ and averaged $16.5 \mathrm{~g} / \mathrm{L}$ reducing sugars.

\section{Detoxification, concentration and supplementation}

A detoxification assay was performed as described in Alves et al. (1998) by first raising the $\mathrm{pH}$ to 7.0 with commercial calcium oxide and then decreasing it to $\mathrm{pH} 5.5$ with sulphuric acid. Active charcoal ( $3 \% \mathrm{w} / \mathrm{v})$ was added, and incubation at $200 \mathrm{rpm}$ and $30{ }^{\circ} \mathrm{C}$ for $1 \mathrm{~h}$ was performed. The precipitates resulting after each procedure were removed by vacuum filtration and separated by centrifugation at $10,000 \mathrm{rpm}$ for $10 \mathrm{~min}$. The hydrolysate was maintained at $4{ }^{\circ} \mathrm{C}$ until use. To obtain the concentration of $40 \mathrm{~g} / \mathrm{L}$ reducing sugars, the hydrolysate was transferred to glass beakers without covering and maintained at $65^{\circ} \mathrm{C}$ in a water bath. The concentration of reducing sugars was monitored periodically. To prepare the fermentation medium, the hydrolysate $\mathrm{pH}$ was adjusted to 5.5 with $10 \mathrm{~mol} / \mathrm{L}$ $\mathrm{NaOH}$, and the precipitated solids were separated by vacuum-filtration and centrifugation from the liquid.

The concentrated hydrolysate was supplemented (or not) with yeast extract at a proportion of $3 \mathrm{~g} / \mathrm{L}(\mathrm{w} / \mathrm{v})$ and then autoclaved at $120{ }^{\circ} \mathrm{C}$ for $15 \mathrm{~min}$. For the hydrolysate without detoxification, the concentration step was carried out right after the hydrolysated bagasse was pressed and filtered.
Inoculum preparation and cultivation conditions

The inoculum was prepared by inoculating two loops of yeast cells in $10 \mathrm{~mL}$ of YPD broth and incubating overnight at $30{ }^{\circ} \mathrm{C}$ under agitation at $150 \mathrm{rpm}$. Then, the yeast cells were washed with saline solution $(\mathrm{NaCl} 0.85 \%)$, centrifuged and added to new YPD broth for a new round of growth. The procedures were repeated until a concentration of $\sim 1 \mathrm{~g} / \mathrm{L}$ dried biomass (nearly $\mathrm{OD}_{600 \mathrm{~nm}}=2$ ) was achieved. The inoculated flasks (500-mL Erlenmeyer flasks with a $200-\mathrm{mL}$ final volume of hydrolysate) were incubated at $30{ }^{\circ} \mathrm{C}$ in a shaker at $150 \mathrm{rpm}$ for $144 \mathrm{~h}$. Samples were removed every $24 \mathrm{~h}$ for analysis.

\section{Analytical methods}

Biomass $(\mathrm{g} / \mathrm{L})$ was determined by the conversion of absorbance values obtained at $600 \mathrm{~nm}$ in a Bio-Mate ${ }^{\circledR}$ spectrophotometer utilizing a standard curve absorbance versus dried biomass (cell mass dried at $105^{\circ} \mathrm{C}$ until a constant weight was achieved). In the cell-free samples (centrifuged samples at $4000 \mathrm{rpm}$ for $5 \mathrm{~min}$ ), $\mathrm{pH}$ was determined with a digital $\mathrm{pH}$-meter; reducing sugars were determined by the 3,5-dinitrosalycilic acid method (Miller 1959) using a standard curve of absorbance versus xylose concentration; and alcohol production was determined after distillation of the samples by measuring the alcohol concentration with a digital densimeter (Anton-Paar). After centrifugation of the bagasse hydrolysate samples, the supernatant was diluted and filtered using a Sep-Pack Cartridge C18 (Millipore) filter. Glucose, xylose, arabinose, xylitol and acetic acid were determined by HPLC (Agilent Technologies 1260 Infinity with a refraction index detector) using a Bio-Rad Aminex HPX-87H $(300 \times 7.8 \mathrm{~mm})$ column at $45^{\circ} \mathrm{C}$ with a sample injection of $20 \mu \mathrm{L}$, a mobile phase of $0.05 \mathrm{~mol} / \mathrm{L} \mathrm{H}_{2} \mathrm{SO}_{4}$ and a flow rate of $0.6 \mathrm{~mL} / \mathrm{min}$. Samples of the hydrolysate before detoxification and after detoxification were diluted and filtered in HSWP membranes $(0.45 \mu \mathrm{m}$ porosity) for the analysis of furanes (furfural and hydroxymethylfurfural) and lignin-derived compounds (vanillin, syringic acid, gallic acid, pyrocatechol, furoic acid, vanillic acid, paracumeric acid and ferulic acid) by HPLC (Agilent Technologies 1260 Infinity with a refraction index detector) using a Waters Spherisorb C18 $5 \mu \mathrm{m}$ ODS2 $(4.6 \times 100 \mathrm{~mm})$ column at room temperature, acetonitrile/water eluent (1:8 with $1 \%$ acetic acid), a flow rate of $0.8 \mathrm{~mL} / \mathrm{min}$, a sample injection of $20 \mu \mathrm{L}$ and a UV detector at $276 \mathrm{~nm}$.

\section{Calculation of fermentative parameters}

Ethanol, xylitol and biomass yields (g/g sugars) were calculated based on the ratio of the product concentration to the substrate consumed (reducing sugar concentration for 
synthetic media and the sum of glucose, xylose and arabinose concentrations for hydrolysate media). Sugar consumption (\%) was calculated as a percentage of sugar consumed in relation to the initial sugar concentration. Ethanol productivity $(\mathrm{g} / \mathrm{L} \mathrm{h})$ was determined by the ratio of ethanol concentration to the fermentation time. Specific growth rate $\left(\mathrm{h}^{-1}\right)$ was calculated first by plotting 'In biomass' versus 'time' in the exponential phase of the growth and then by considering the slope of this curve to be the specific growth rate.

\section{Statistical analysis}

Statistical analysis (ANOVA) was performed using Statistica version 6.0 , and data were considered to be significantly different when $P<0.05$.

\section{Results}

A previous study demonstrated that the strain of M. guilliermondii isolated here exhibited gas formation from xylose and arabinose in a Durham tube test (Martini 2014), and for this reason it was initially surveyed for its ability to grow in synthetic pentose-based media under different $\mathrm{pH}$ values. The yeast grew in xylose, arabinose and glucose at the same rate at the initial medium $\mathrm{pH} 5.5$. At 4.5, the yeast grew slower in arabinose and for the other carbon sources there was no difference at different $\mathrm{pH}$ values. Higher sugar consumption was observed when glucose was used; however, there was no sugar exhaustion within $60 \mathrm{~h}$ of cultivation (Table 1). There were not any large variations in $\mathrm{pH}$ values during growth, regardless of the carbon source and initial $\mathrm{pH}$.

When a higher xylose concentration $(40 \mathrm{~g} / \mathrm{L})$ was used with a higher initial cell concentration, sugar was exhausted within $96 \mathrm{~h}$ of fermentation in the assay with $\mathrm{pH} 4.5$. No difference was observed for biomass and alcohol yields in the media with $\mathrm{pH} 4.5$ or 5.5. The growth rate was lower in this experiment compared to the previous one (Table 2).
For the sugarcane bagasse hydrolysates, the detoxification process resulted in decreased concentrations for most of the inhibitors present in the concentrated hydrolysates. There was also a loss in sugar concentrations, ranging from 7.8, 10.6 and $30.7 \%$ for glucose, xylose and arabinose, respectively (Table 3 ).

An analysis of variance considering the main effects of detoxification, supplementation and time and also their interactions is shown in Table 4. For biomass, $\mathrm{pH}$, residual glucose and arabinose, the effects of detoxification are dependent on supplementation (significant interaction). However, for residual reducing sugars, xylose, acetic acid, and the production of xylitol and ethanol, there was no significant interaction between detoxification and supplementation. For xylitol production, supplementation was significant whereas detoxification was not. For the others (residual reducing sugars, xylose, acetic acid and ethanol production), both detoxification and supplementation were significant individually.

Fermentation results with the bagasse hydrolysates are shown in Table 5 and Fig. 1. At the end of the fermentation time, a $350 \%$ increase in biomass was obtained in detoxified hydrolysates whereas supplementation with $3 \mathrm{~g} / \mathrm{L}$ yeast extract increased biomass production by approximately $40 \%$ (Table 5). An increase in medium $\mathrm{pH}$ was noticed for all fermentations; the lowest residual reducing sugars were obtained in supplemented media (Table 5). The addition of yeast extract had a significant effect on xylose consumption because there was a residual concentration of $8.5-12.5 \mathrm{~g} / \mathrm{L}$ xylose in the media at the end of the fermentation period in hydrolysates without supplementation. Arabinose was only consumed when glucose or xylose was not available anymore, which could be observed in detoxified hydrolysates with supplementation (Fig. 1). Otherwise, both ethanol and xylitol were also consumed after $144 \mathrm{~h}$ of fermentation, likely resulting in higher biomass production (Table 5).

Glucose was consumed faster by M. guilliermondii in the hydrolysates regardless of detoxification and supplementation with yeast extract. Within $48 \mathrm{~h}$, the glucose concentration was close to zero. Acetic acid was detected

Table 1 Growth parameters of M. guilliermondii in synthetic medium with glucose, xylose or arabinose as the sole carbon source (20 g/L), at initial $\mathrm{pH}$ values of 4.5 and $5.5,30{ }^{\circ} \mathrm{C}, 160 \mathrm{rpm}$

\begin{tabular}{lllll}
\hline Carbon source & $\mathrm{pH}$ & $\begin{array}{l}\text { Specific growth } \\
\text { rate }\left(\mu, \mathrm{h}^{-1}\right)\end{array}$ & $\begin{array}{l}\text { Biomass yield } \\
(\mathrm{g} / \mathrm{g} \text { sugars })^{\mathrm{a}}\end{array}$ & $\begin{array}{l}\text { Sugar } \\
\text { consumption }(\%)^{\mathrm{a}}\end{array}$ \\
\hline Glucose & 4.5 & 0.066 & 0.14 & 37.2 \\
Xylose & 5.5 & 0.078 & 0.08 & 58.8 \\
& 4.5 & 0.078 & 0.17 & 29.7 \\
Arabinose & 5.5 & 0.071 & 0.14 & 32.3 \\
& 4.5 & 0.053 & 0.19 & 24.9 \\
\hline
\end{tabular}

${ }^{\mathrm{a}}$ Values obtained in $60 \mathrm{~h}$ of cultivation were considered 
Table 2 Growth and fermentation parameters of M. guilliermondii in synthetic medium with xylose as the sole carbon source (40 g/L), at initial $\mathrm{pH}$ values of 4.5 and $5.5,30^{\circ} \mathrm{C}, 160 \mathrm{rpm}$

\begin{tabular}{lllll}
\hline $\mathrm{pH}$ & $\begin{array}{l}\text { Specific growth } \\
\text { rate }\left(\mu, \mathrm{h}^{-1}\right)\end{array}$ & $\begin{array}{l}\text { Biomass yield } \\
(\mathrm{g} / \mathrm{g} \text { sugars })^{\mathrm{a}}\end{array}$ & $\begin{array}{l}\text { Alcohol yield } \\
(\mathrm{g} / \mathrm{g} \text { sugars })^{\mathrm{a}}\end{array}$ & $\begin{array}{l}\text { Sugar } \\
\left.\text { consumption }^{(\%)}\right)^{\mathrm{a}}\end{array}$ \\
\hline 4.5 & 0.043 & 0.14 & 0.02 & 98.1 \\
5.5 & 0.044 & 0.15 & 0.04 & 90.4 \\
\hline
\end{tabular}

a Values obtained in $120 \mathrm{~h}$ of cultivation were considered

Table 3 Concentrations of inhibitors and sugars in the concentrated sugarcane bagasse hydrolysate before and after detoxification

\begin{tabular}{lrl}
\hline Type of substance & Non-detoxified hydrolysate & Detoxified hydrolysate \\
\hline Inhibitor (mg/L) & 145.19 & \\
5-Hydrohymethylfurfural & 6.52 & 5.09 \\
Furfural & 96.71 & 11.45 \\
Ferulic acid & 10.69 & 0.01 \\
Gallic acid & 28.46 & 12.22 \\
Pyrocatechol & 207.03 & 0 \\
Furoic acid & 9.66 & 55.16 \\
Vanillic acid & 38.84 & 2.00 \\
Syringic acid & 43.89 & 0.53 \\
Vanillin & 124.14 & 0 \\
Paracumeric acid & & 0.01 \\
Sugar (g/L) & 2.95 & 2.72 \\
Glucose & 28.92 & 25.86 \\
Xylose & 2.51 & 1.74 \\
Arabinose & & \\
\hline
\end{tabular}

Table 4 Analysis of variance of the effects of detoxification (Detox), supplementation (Suppl) with yeast extract ( $3 \mathrm{~g} / \mathrm{L})$ and time over the growth and fermentation parameters of $M$. guilliermondii in sugarcane bagasse hydrolysate

\begin{tabular}{|c|c|c|c|c|c|c|c|c|c|}
\hline \multirow[t]{2}{*}{ Source of variation } & \multicolumn{9}{|c|}{ Mean Square (MS) } \\
\hline & Biomass & $\mathrm{pH}$ & Reducing sugars & Xylose & Acetic acid & Glucose & Arabinose & Xylitol & Ethanol \\
\hline Detoxification & $774.67 *$ & $0.01^{\mathrm{ns}}$ & $388.88 *$ & $49.16^{*}$ & $18.08^{*}$ & $0.10^{*}$ & $1.48 *$ & $0.32^{\mathrm{ns}}$ & $2.93 *$ \\
\hline Supplementation & $54.27^{*}$ & $0.60 *$ & $1279.88 *$ & $510.58 *$ & $1.50 *$ & $0.01^{\mathrm{ns}}$ & $0.88 *$ & $31.98^{*}$ & $8.40^{*}$ \\
\hline Time & $163.94 *$ & $6.88 *$ & $807.40 *$ & $493.32 *$ & $15.15^{*}$ & $9.67 *$ & $1.45^{*}$ & $8.15^{*}$ & $3.00 *$ \\
\hline Detox*Suppl & $28.93 *$ & $0.29 *$ & $5.04^{\mathrm{ns}}$ & $3.25^{\mathrm{ns}}$ & $0.01^{\mathrm{ns}}$ & $0.04 *$ & $0.24 *$ & $0.17^{\mathrm{ns}}$ & $0.15^{\mathrm{ns}}$ \\
\hline Detox*Time & $70.08^{*}$ & $0.75^{*}$ & $9.07 *$ & $7.52 *$ & $1.13 *$ & $0.04 *$ & $0.38^{*}$ & $2.44 *$ & $1.23 *$ \\
\hline Suppl*Time & $5.47 *$ & $0.19 *$ & $59.62 *$ & $44.46^{*}$ & $0.71 *$ & $0.02^{\mathrm{ns}}$ & $0.38^{*}$ & $4.83 *$ & $0.99 *$ \\
\hline Detox*Suppl*Time & $3.45^{*}$ & $0.13 *$ & $8.14 *$ & $7.27 *$ & $0.59 *$ & $0.02^{\mathrm{ns}}$ & $0.32 *$ & $2.16^{*}$ & $1.76^{*}$ \\
\hline Error & 0.19 & 0.02 & 1.92 & 1.05 & 0.10 & 0.07 & 0.04 & 0.45 & 0.05 \\
\hline
\end{tabular}

ns non-significant

* Statistically significant at $P<0.05$

in higher amounts in non-detoxified hydrolysates, and it was consumed by the yeast. Ethanol and xylitol were produced more significantly in supplemented hydrolysates regardless of the detoxification (Fig. 1).

Fermentation parameters are depicted in Table 6. Supplementation had a greater impact on yields and productivity than detoxification. Ethanol and xylitol yields and productivity are similar or higher in non-detoxified supplemented hydrolysate than in detoxified supplemented hydrolysate. Detoxification brought about greater biomass production, which was detrimental to alcohol or xylitol production. 
Table 5 Effects of detoxification and supplementation with yeast extract ( $3 \mathrm{~g} / \mathrm{L})$ on biomass production, medium $\mathrm{pH}$ and reducing sugars (RS) in the fermentation of $M$. guilliermondii in sugarcane bagasse hydrolysates, $\mathrm{pH} 5.5,30^{\circ} \mathrm{C}, 160 \mathrm{rpm}$

\begin{tabular}{|c|c|c|c|c|c|c|c|c|c|c|c|c|}
\hline \multirow[t]{2}{*}{ Time (h) } & \multicolumn{3}{|c|}{$\begin{array}{l}\text { Non-detoxified without } \\
\text { supplementation }\end{array}$} & \multicolumn{3}{|c|}{$\begin{array}{l}\text { Non-detoxified with } \\
\text { suplementation }\end{array}$} & \multicolumn{3}{|c|}{$\begin{array}{l}\text { Detoxified without } \\
\text { supplementation }\end{array}$} & \multicolumn{3}{|c|}{$\begin{array}{l}\text { Detoxified with } \\
\text { supplementation }\end{array}$} \\
\hline & $\begin{array}{l}\text { Biomass } \\
(\mathrm{g} / \mathrm{L})\end{array}$ & $\mathrm{pH}$ & $\begin{array}{l}\mathrm{RS} \\
(\mathrm{g} / \mathrm{L})\end{array}$ & $\begin{array}{l}\text { Biomass } \\
(\mathrm{g} / \mathrm{L})\end{array}$ & $\mathrm{pH}$ & $\begin{array}{l}\mathrm{RS} \\
(\mathrm{g} / \mathrm{L})\end{array}$ & $\begin{array}{l}\text { Biomass } \\
(\mathrm{g} / \mathrm{L})\end{array}$ & $\mathrm{pH}$ & $\begin{array}{l}\mathrm{RS} \\
(\mathrm{g} / \mathrm{L})\end{array}$ & $\begin{array}{l}\text { Biomass } \\
(\mathrm{g} / \mathrm{L})\end{array}$ & $\mathrm{pH}$ & $\begin{array}{l}\mathrm{RS} \\
(\mathrm{g} / \mathrm{L})\end{array}$ \\
\hline 0 & 0.91 & 5.44 & 41.2 & 0.84 & 5.45 & 36.4 & 1.10 & 5.40 & 37.9 & 1.08 & 5.40 & 38.2 \\
\hline 24 & 0.95 & 6.07 & 35.8 & 1.60 & 5.84 & 33.9 & 4.39 & 7.45 & 30.4 & 3.44 & 6.48 & 27.5 \\
\hline 48 & 3.04 & 7.38 & 32.6 & 2.73 & 6.83 & 26.7 & 5.58 & 7.79 & 29.7 & 9.68 & 7.50 & 18.5 \\
\hline 72 & 3.31 & 7.95 & 29.8 & 3.74 & 7.38 & 19.5 & 8.55 & 7.74 & 23.5 & 12.86 & 7.85 & 11.3 \\
\hline 96 & 3.91 & 8.18 & 25.6 & 4.23 & 7.42 & 11.6 & 10.11 & 7.60 & 17.0 & 14.17 & 7.50 & 6.8 \\
\hline 120 & 4.09 & 8.27 & 25.3 & 5.09 & 7.91 & 7.4 & 13.24 & 7.43 & 17.0 & 18.17 & 7.67 & 4.5 \\
\hline 144 & 4.44 & 8.31 & 22.9 & 6.09 & 8.32 & 6.5 & 19.63 & 7.27 & 16.4 & 27.06 & 7.85 & 2.4 \\
\hline
\end{tabular}

Fig. 1 Effects of detoxification and supplementation with yeast extract $(3 \mathrm{~g} / \mathrm{L})$ on the concentration of sugars (xylose, glucose and arabinose), acetic acid and products (xylitol and ethanol) in fermentations by $M$. guilliermondii in sugarcane bagasse hydrolysates. Legend black bar $0 \mathrm{~h}$; gray bar $48 \mathrm{~h}$; white bar $96 \mathrm{~h}$; light gray bar $144 \mathrm{~h}$

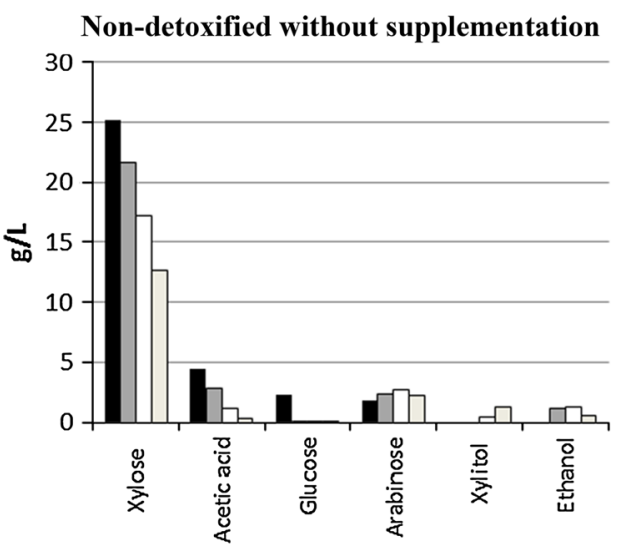

Detoxified without supplementation

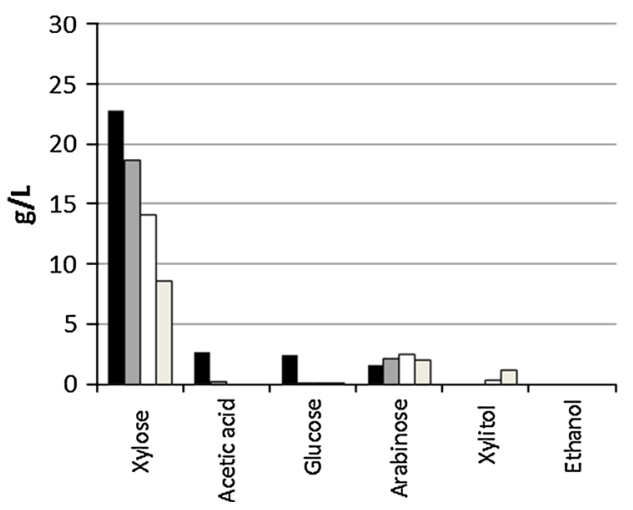

Non-detoxified with supplementation

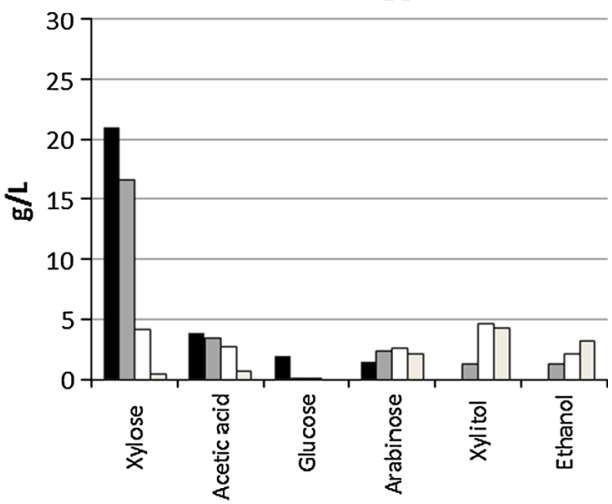

Detoxified with supplementation

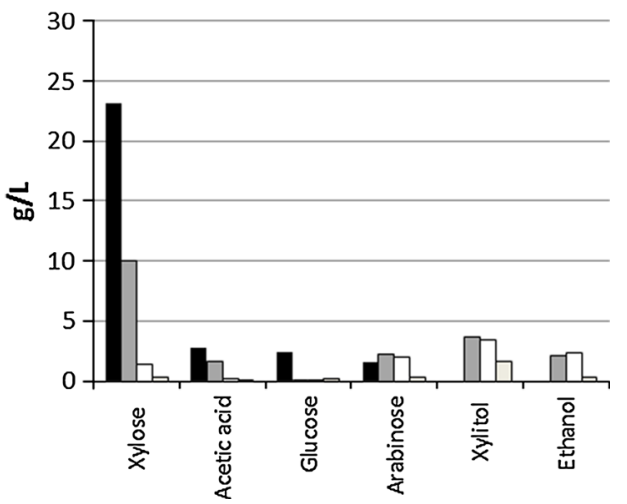

\section{Discussion}

Strains of M. guilliermondii isolated by Cadete et al. (2012) from Amazonian forest reserves did not exhibit xylose fermentation in a Durham tube test in contrast to the strain studied here, which was positive for xylose and arabinose fermentation in a Durham tube test. Similar result for pentose fermentation was found by Matos et al. (2014) for a particular strain of $M$. guilliermondii. There is no doubt that the strain of $M$. guilliermondii isolated from sugarcane juice is able to assimilate xylose efficiently to convert into biomass, but efficient xylose fermentation was not obtained under the conditions utilized in synthetic medium. High sugar consumption and increasing biomass production over time may have resulted in the low alcohol yield.

The next step was to evaluate the yeast performance in bagasse hydrolysates, and for that purpose experiments were designed to verify the influence of detoxification and 
Table 6 Fermentation parameters of $M$. guilliermondii in detoxified and non-detoxified hydrolysates, with and without yeast extract (YE), pH 5.5, $30{ }^{\circ} \mathrm{C}, 160 \mathrm{rpm}$

\begin{tabular}{|c|c|c|c|c|}
\hline \multirow[t]{3}{*}{ Parameter } & \multicolumn{4}{|c|}{ Type of hydrolysate } \\
\hline & \multicolumn{2}{|c|}{ Non-detoxified } & \multicolumn{2}{|l|}{ Detoxified } \\
\hline & Without YE & With YE & Without YE & With YE \\
\hline Ethanol yield (g/g sugars) & $0.13 \mathrm{~b}$ & $0.14 \mathrm{~b}$ & $0 \mathrm{a}$ & $0.10 \mathrm{~b}$ \\
\hline Xylitol yield (g/g sugars) & $0.04 \mathrm{a}$ & $0.19 \mathrm{~b}$ & $0.07 \mathrm{a}$ & $0.14 \mathrm{~b}$ \\
\hline Residual xylose concentration (g/L) & $17.18 \mathrm{c}$ & $0.38 \mathrm{a}$ & $8.54 \mathrm{~b}$ & $1.39 \mathrm{a}$ \\
\hline Fermentation time $(\mathrm{h})^{\mathrm{a}}$ & 96 & 144 & 144 & 96 \\
\hline Productivity (g ethanol/L h) & $0.013 \mathrm{~b}$ & $0.022 \mathrm{bc}$ & $0 \mathrm{a}$ & $0.024 \mathrm{c}$ \\
\hline
\end{tabular}

Different letters in the lines mean statistical difference at $P<0.05$

${ }^{\text {a }}$ Lowest fermentation time in which the highest ethanol production was reached supplementation with yeast extract on yeast performance in sugarcane bagasse hydrolysates. One of the main characteristics of this particular fermentation is the fact that hydrolysates are multiple-sugar substrates. Yeasts cultivated in a mix of sugars (hexoses and pentoses) may exhibit an inhibition or delay in xylose utilization when glucose is present (Gong et al. 1999). Concentrations above $20 \mathrm{~g} / \mathrm{L}$ glucose repress xylose utilization even when yeast species with high affinities for pentoses are utilized, such as $P$. stipitis (Hähn-Hagerdal et al. 1991). K. marxianus and Candida materiae are better glucose-fermenters than xylosefermenters, whereas $S$. passalidarum and $C$. shehatae exhibit higher ethanol production from xylose than glucose (Mouro 2012). The concentration of glucose in our hydrolysates was below $5 \mathrm{~g} / \mathrm{L}$, which may not be enough to cause the repression of xylose utilization. When utilizing hydrolysates from sugarcane straw and $P$. stipitis, glucose was completely consumed within $15 \mathrm{~h}$ whereas xylose was consumed from the start to the end of $110 \mathrm{~h}$ of fermentation, although at a slower rate in the presence of glucose (Moutta 2009).

Both five-carbon sugars (xylose and arabinose) are directly involved in pentose metabolism and are primarily responsible for the activation of xylose reductase and xylitol dehydrogenase in $P$. tannophilus and Candida tenuis (Bolen and Detroy 1985; Kern et al. 1997). In our experiments, the consumption of arabinose did not result in higher production of ethanol and xylitol. The assimilation pathway of arabinose in yeasts is quite similar to the xylose pathway (Shi et al. 2000); however, arabinose was consumed more slowly than xylose, which was also observed by Silva and Roberto (2001) in bagasse hydrolysate and in synthetic medium (Felipe et al. 1995).

Acetic acid was also consumed by $M$. guilliermondii in this work. Its concentration in hydrolysates is dependent on the biomass nature and the hydrolysis process, varying from 0.6 to $12 \mathrm{~g} / \mathrm{L}$. In our work, the concentration of acetic acid did not rise beyond $5 \mathrm{~g} / \mathrm{L}$. The microbial tolerance to this acid may vary among yeast species and with cultivation conditions (Helle et al. 2003). The yeast Issatchenkia occidentalis was able to consume acetic acid from sugarcane bagasse hydrolysate (Gonçalves et al. 2013), and this characteristic of biological detoxification should be further evaluated in our strain.

A strain of M. guilliermondii isolated from the abdomen contents of termites exhibited high final cell viability and an increase in the medium $\mathrm{pH}$ (from 5.0 to 7.6) in sugarcane bagasse hydrolysate, resulting in neutralization of the hydrolysate. The fermentative efficiency corresponded to $18.6 \%$ of the maximum theoretical yield (Matos et al. 2014). In our work, the best ethanol yield ( $0.13 \mathrm{~g} / \mathrm{g}$ sugars) corresponded to $25.4 \%$ fermentative efficiency.

In addition to ethanol, xylitol was also produced by the yeast strain employed. The bioconversion of xylose to xylitol is influenced by several factors, of which the aeration level is the most important (Parajó et al. 1998; Roberto et al. 1999). Under aerobic conditions, a deviation in microbial metabolism to cell production may occur with diminished xylitol production. Under oxygen-limited conditions, xylitol may be accumulated (Náhlik et al. 2003). In our experiments, the agitation level was the same for all four fermentation trials, consequently resulting in the same aeration level. The difference observed for xylitol production should thus be credited to nutritional supplementation with yeast extract.

We must consider that the best sugars-to-ethanol conversion yield $(0.14 \mathrm{~g} / \mathrm{g})$ and xylitol yield $(0.19 \mathrm{~g} / \mathrm{g})$ and productivity $(0.022 \mathrm{~g} / \mathrm{L} \mathrm{h})$ under the present experimental conditions are still low under the conditions utilized here. The best results were obtained in non-detoxified hydrolysate with supplementation. Strategies for detoxification and supplementation with yeast extract have been employed with better results for ethanol productivity by $P$. stipitis $(0.13 \mathrm{~g} / \mathrm{L}$ h, Canilha et al. 2010; $0.2 \mathrm{~g} / \mathrm{L}$ h, Cadete et al. 2012) and $S$. shehatae $(0.11-0.15 \mathrm{~g} / \mathrm{L} \mathrm{h}$, Martiniano et al. 2013) in bagasse hydrolysate.

The results, specifically the ability to grow in non-detoxified hydrolysates, suggest good prospects for the use of $M$. guilliermondii in such a fermentation process because the 
detoxification step causes the loss of sugar, and it is energyand time-consuming. This result is interesting because many yeasts cannot withstand the presence of inhibitors released during the acid hydrolysis of hemicellulose.

It is imperative to evaluate other characteristics of this fermentation to obtain better results. In this sense, even considering the specificities of the process and of the substrates, we can learn a great deal from experience with 1st generation ethanol. The influence of initial cell concentration, for example, has not gained much attention yet. High cell densities are utilized in distilleries for ethanol produced from sugarcane musts; this strategy decreases the fermentation time and increases the process productivity (Amorim et al. 2011). In hydrolysates, lower cell densities have been utilized, such as $1.5-3.0 \mathrm{~g} / \mathrm{L}$ with $P$. stipitis and C. shehatae (Sreenath and Jeffries 2000).

Aeration is crucial for the production of ethanol and byproducts. The deviation of energy to xylitol production exerts effects on the production of ethanol, which is the main product, but the industrial importance of xylitol is quite considerable. It is a natural sweetener utilized as a sugar substitute and has clinical properties (Canettieri et al. 2002). The optimization of culture conditions may result in the production of ethanol or xylitol in higher titres by the yeast $M$. guilliermondii.

We conclude that supplementation with yeast extract at a concentration as low as $3 \mathrm{~g} / \mathrm{L}$ exerted a remarkable effect on fermentation parameters, regardless of detoxification. It maybe that the addition of other supplements (peptone and or malt extract) or higher concentrations leads to higher yields, and in this case, detoxification could make the difference. Further investigation is required to verify these possibilities.

Acknowledgments This work was supported financially by Instituto Nacional de Ciência e Tecnologia do Bioetanol-INCT do Bioetanol (FAPESP 2008/57908-6 and CNPq 574002/2008-1) and Coordenação de Aperfeiçoamento de Pessoal de Nivel Superior (fellowship grants to C. Martini and C. B. Codato). The authors are greatly indebted to Dr. Ines Conceição Roberto (EEL-USP) for the chromatographic analysis.

\section{References}

Alves LA, Felipe MGA, Silva JBAE, Silva SS, Prata AMR (1998) Pretreatment of sugarcane bagasse hemicellulose hydrolysate for xylitol production by Candida guilliermondii. Appl Biochem Biotechnol 70-72:89-98

Amorim HV, Lopes ML, Oliveira JVC, Buckeridge MS, Goldman GH (2011) Scientific challenges of bioethanol production in Brazil. Appl Microbiol Biotechnol 91:1267-1275. doi:10.1007/ s00253-011-3437-6

Antunes FAF, Milessi TSS, Chandel AK, Moraes VP, Rosa CA, Silva SS (2013) Evaluatin of a new yeast from Brazilian biodiversity Scheffersomyces shehatae UFMG-HM 52.2, for pentose sugars conversion into bioethanol. Biochem Biotechnol Rep 2(4):1-7. doi: $10.5433 / 2316-5200.2013 \mathrm{v} 2 \mathrm{n} 4 \mathrm{p} 1$

Araujo FV, Soares CA, Hagler AN, Mendonça-Hagler LC (1995) Ascomycetous yeast communities of marine invertebrates in a southeast Brazilian mangrove ecosystem. Antonie Van Leeuwenhoek 68:91-99

Bolen PL, Detroy RW (1985) Induction of NADPH-linked D-xylose reductase and NAD-linked xylitol dehydrogenase activities in Pachysolen tannophilus by D-xylose, L-arabinose or D-galactose. Biotechnol Bioeng 27:302-307

Cadete RM, Santos RO, Melo MA, Mouro A, Gonçalves DL, Stambuk BU, Gomes FCO, Lachance MA, Rosa CA (2009) Spathaspora arboriae sp. nov., a D-xylose fermenting yeast species isolated from rotting wood in Brazil. FEMS Yeast Res 9:1338-1342. doi:10.1111/j.1567-1364.2009.00582.x

Cadete RM, Melo MA, Dussan KJ, Rodrigues RCLB, Silva SS, Zilli Vital MJS, Gomes FCO, Lachance MA, Rosa C (2012) Diversity and physiological characterization of D-xylose- fermenting yeasts isolated from the Brazilian Amazonian forest. PLoS One 7:1-11. doi:10.1371/journal.pone.0043135

Canettieri EV, Silva JBA, Felipe MGA (2002) Obtenção biotecnológica de xilitol a partir de cavacos de eucalipto. Braz J Pharm Sci 38(3):323-331

Canilha L, Carvalho W, Felipe MGA, Silva JBA, Giulietti M (2010) Ethanol production from sugarcane bagasse hydrolysate using Pichia stipitis. Appl Biochem Biotechnol 161:84-92. doi:10. 1007/s12010-009-8792-8

Capriotti A, Ranieri L (1964) Yeasts in green house environment I. From soil, flowers and animals. Arch Mikrobiol 48:325-331

Carneiro LM (2011) Avaliação de estratégias de adaptação da levedura Pichia stipitis em hidrolisado hemicelulósico de palha de arroz visando a produção de etanol. Dissertation, Escola de Engenharia de Lorena-Universidade de São Paulo

Chandel KA, Chandrasekhar G, Radhika K, Ravinder R, Ravindra P (2011) Bioconversion of pentoses sugar into ethanol: a review and future directions. Biotechnol Mol Biol Rev 6:8-20

Coda R, Rizzello CG, Di Cagno R, Trani A, Cardinali G (2013) Antifungal activity of Meyerozyma guilliermondii: identification of activity compounds synthesized during dough fermentation and their effect on long-term storage of wheat bread. Food Microbiol 33:243-251. doi:10.1016/j.fm.2012.09.023

Diriye FU, Giansante C, Scorzetti G, Zilli R (1993) Indagine preliminare sulla ecologia dei lieviti delle acque del litorale Abruzzese. Ann Fac Agr Perugia XLV:339-345

Felipe MGA, Vieira DC, Vitolo M, Silva SS, Roberto IC, Mancilha IM (1995) Effect of acetic acid on xylose fermentation to xylitol by Candida guilliermondii. J Basic Microbiol 35(3):171-177

Gonçalves BMG, Jesus JYFM, Peron HB, Freitas WLC, Pagnocca FC, Silva SS (2013) Consumo de açúcares e ácido acético durante a destoxificação biológica de hidrolisado hemicelulósico pela levedura Issatchenkia occidentalis. Biochem Biotechnol Rep 2(3):372-375

Gong CS, Cao NJ, Du J, Tsao GT (1999) Ethanol production from renewable resources. Adv Biochem Eng Biotechnol 65:207-241

Guo D, Dai MI, Zhou ZP (2012) Molecular identification and morphological analysis of yeast in spoiled orange juice. Food Sci 33(9):131-137

Hähn-Hagerdal B, Linden T, Senac T, Skoog K (1991) Ethanolic fermentation of pentoses in lignocellulose hydrolysate. Appl Biochem Biotechnol 28-29(1):131-144

Helle S, Cameron D, Lam J, White B, Duff S (2003) Effect of inhibitory compounds found in biomass hydrolysates on growth and xylose fermentation by a genetically engineered strain of $S$. cerevisiae. Enzyme Microb Technol 33:786-792

Kern M, Haltrich D, Nidetzky B, Kulbe KD (1997) Induction of aldose reductase and xylitol dehydrogenase activities in Candida tenuis CBS4435. FEMS Microbiol Lett 149:31-37 
Kumar A, Singh LK, Ghosh S (2009) Bioconversion of lignocelulosic fraction of water-hyacinth (Eichhornia crassipes) hemicelulose acid hydrolysate to ethanol by Pichia stipitis. Bioresour Technol 100:3293-3297. doi:10.1016/j.biortech.2009.02.023

Laluce C, Schenberg ACG, Gallardo JCM, Coradello LFC, Pombeiro-Sponchiado SR (2012) Advances and developments in strategies to improve strains of Saccharomyces cerevisiae and processes to obtain the lignocellulosic ethanol-a review. Appl Biochem Biotechnol 166:1908-1926. doi:10.1007/s12010012-9619-6

Lima JR, Gonçalves LRB, Brandão LR, Rosa CA, Viana FMP (2012) Isolation, identification and activity in vitro of killer yeasts against Colletotrichum gloeosporioides isolated from tropical fruits. J Microbiol 52:1-10. doi:10.1002/jobm.201200049

Martini C (2014) Isolamento, identificação e caracterização de linhagem de levedura quanto ao crescimento e fermentação utilizando meios sintéticos com pentoses e hidrolisado de bagaço de cana-de-açúcar. Thesis, Universidade Estadual Paulista Julio de Mesquita Filho

Martiniano S, Chandel AK, Soares LCSR, Pagnocca FC, Silva SS (2013) Evaluation of novel xylose-fermenting yeast strains from Brazilian forests for hemicellulosic ethanol production from sugarcane bagasse. 3 Biotech 3:345-352. doi:10.1007/s13205013-0145-1

Matos ITSR, Cassa-Barbosa LA, Galvão RSM, Nunes-Silva CG, Astolfi-Filho S (2014) Isolation, taxonomic identification and investigation of the biotechnological potential of wild-type Meyerozyma guilliermondii associated with Amazonian termites able to ferment D-xylose. Biosci J 30(1):260-266

Miller GL (1959) Use of dinitrosalicylic acid reagent for determination of reducing sugar. Anal Chem 31:426-428. doi:10.1021/ ac60147a030

Mouro A (2012) Fermentação de xilose e celobiose por leveduras isoladas da biodiversidade brasileira. Dissertation, Universidade Federal de Santa Catarina

Moutta RO (2009) Hidrólise ácida de palha de cana-de-açúcar para obtenção de hidrolisado hemicelulósico visando à utilização em processos de produção de bioetanol. Dissertation, Escola de Engenharia de Lorena
Náhlik J, Palatová M, Gírio F, Roseiro C (2003) Model identification and physiological control of xylitol production using Debaryomyces hansenii. Process Biochem 38(12):1695-1705

Nakayan P, Hameed A, Singh S, Young LS, Hung MH, Young CC (2013) Phosphate-solubilizing soil yeast Meyerozyma guilliermondii CC1 improves maize (Zea mays L.) productivity and minimizes requisite chemical fertilization. Plant Soil. doi:10. 1007/s11104-013-1792-z

Olsson L, Hahn-Hagerdal B (1996) Fermentation of lignocellulosic hydrolysates for ethanol production. Enzyme Microb Technol 18:312-331. doi:10.1016/0141-0229(95)00157-3

Parajó JC, Dominguez H, Dominguez JM (1998) Biotechnological production of xylitol. Part 1: interest of xylitol and fundamentals of its biosynthesis. Bioresour Technol 65:191-201

Rao RS, Bhaddra B, Shivaji S (2008) Isolation and characterization of ethanol producing yeast from fruits and tree barks. Lett Appl Microbiol 47:19-24. doi:10.1111/j.1472-765X.2008.02380.x

Rao RS, Prakasham RS, Prasad KK, Rajesham S, Sarma PN, Venkateswar RL (2004) Xylitol production by Candida $s p$ : parameter optimization using Taguchi approach. Process Biochem 39:951-956

Roberto IC, Mancilha IM, Sato S (1999) Influence of kLa on bioconversion of rice straw hemicellulosic hydrolysate to xylitol production. Bioprocess Eng 21:505-508

Shi NQ, Prahl K, Hendrick J, Cruz J, Lu P (2000) Characterization and complementation of a Pichia stipitis mutant unable to grow on Dxylose or Larabinose. Appl Biochem Biotechnol 84-86:201-215

Sibirny A (1996) Pichia guilliermondii. In: Wolf K (ed) Nonconventional yeasts in biotechnology. Springer, Berlin, pp 255-275

Silva CJ, Roberto IC (2001) Improvement of xylitol production by Candida guilliermondii FTI 20037 previously adapted to rice straw hemicellulosic hydrolysate. Lett Appl Microbiol 32(4):248-252

Souza AP, Leite DCC, Pattathil S, Hahn MG, Buckeridge MS (2012) Composition and structure of sugarcane cell wall polysaccharides: implications for second-generation bioethanol production. Bioenergy Res. doi:10.1007/s12155-012-9268-1

Sreenath HK, Jeffries TW (2000) Production of ethanol from wood hydrolyzate by yeast. Bioresour Technol 72:253-260. doi:10. 1016/S0960-8524(99)00113-3 